\title{
SITI HAWA DALAM PERSPEKTIF MUHAMMAD ASAD DAN CHRISTOPH BARTH
}

\author{
Mina Mudrikah Zain, Izzah Faizzah Siti Rusydati Khairani, Ahmad Izzan \\ UIN Sunan Gunung Djati Bandung \\ Jl. AH. Nasution 105 Cibiru Bandung \\ Email :minamudrikahzain@gmail.com
}

\begin{abstract}
Abstrak
Penelitian ini bertujuan mengetahui ayat-ayat yang membahas Siti Hawa dalam Alquran dan Alkitab, melaluipenafsiran Muhammad Asad dan Christoph Barth tentang Siti Hawa. Penelitianini juga berusahauntukmengetahui 'ibrah kisah Hawa dalam pandangan kedua tokoh tersebut.Metode yang digunakan dalam penelitian ini adalah analisis deskriptif komparatif. Jenis penelitiannya kualitatif, berbentuk library research. Data yang diperoleh dianalisa dengan pendekatan metode komparatif yakni membandingkan pemikiran kedua tokoh untuk diketahui persamaan dan perbedaan penafsirannya. Hasil dari penelitian ini menunjukkan bahwa dalam Alquran Hawa disebutkan dengan kata zawjahā dan zawjuka. Kata zawjahā terulang tiga kali, kata zawjuka terulang dua kali. Kisah Hawa dimuat dalam 21 ayat yang tersebar dalam enam surah dalam Alquran dan dalam Alkitab terdapat pada Kitab Kejadian: 2 dan 3. Selanjutnya, Asad dan Barth berbeda pendapat dalam materi penciptaan Hawa, tetapi keduanya sama-sama mengangkat suara dan hak perempuan yang dalam sejarahbiasanya dianggap sebagai makhluk kedua. Asad dan Barth memandang kisah kejatuhan Adam dan Hawa sebagai kesadaran manusia akan ketidakberdayaan totalnya dan sangat bergantung pada petunjuk Allah. Asad berpendapat bahwa Adam dan Hawa diampuni Allah. Namun, 'ibrah dari kisahnya menunjukkan bahwa jika manusia mengikuti godaan setan maka ia akan sengsara. Adapun Barth memandang bahwa akibat perbuatan mereka harus dibayar dengan hukuman, namun ia tidak sepakat dengan paham laki-laki berkuasa atas perempuan dan adanya konsep "dosa warisan".
\end{abstract}

\section{Keywords :}

Siti Hawa, Muhammad Asad, Christoph Barth, 'ibrah

\begin{abstract}
This study aims to find out verses that discuss Siti Hawa in the Qur'an and the Bible under the interpretation of Muhammad Asad and Christoph Barth. This research also examines the moral values behind the story of Siti Hawa from both scholars. This research employs qualitative method with descriptive-comparative analysis. In comparative analysis, the data are comparedbetween two scholars related to the stories of Hawa in term of similarities as well as differences. The results of this study indicate that in the Qur'an Hawa is represented by the words zawjaha and zawjuka. The word zawjaha $\bar{a}$ is repeated three times, while the word zawjuka is repeated twice. Hawa's story is contained in 21 verses scattered in six suras in the Qur'an, and in the Bible found in the Book of Genesis: 2 and 3. The interpretation of the story of Hawa fromAsad and Barth points of view are highlights as follow: first, Asad and Barth show disaggrement related to the origin of Hawa's creation. However, both are agree in term that Hawa's origin of creation does not appointed her to be positioned secondary to Adam (male). Hawa (woman) is equal to Adam (man) as human being. Furthermore, Asad and Barth opinion related to the story of the fall of Adam and Hawafrom Heaven means as human consciousness of total helplessness and rely heavily on God's guidance. Asad argued that Adam and Hawa were forgiven by God. However, 'ibrah from this story shows that if human follows Satan's temptations s/he will be miserable. As for Barth, he considers that the consequences of their actions must be paid with punishment, but he does not agree with the concept of "inherited sin" as believed by majority of Christians.
\end{abstract}

Keywords:

Eve, Muhammad Asad, Christoph Barth, message of the story

\section{A. PENDAHULUAN}

Yahudi, Kristen, dan Islam mengakui adanya sosok perempuan pertama di dunia 
yakni Hawa. Walau demikian, penamaan Hawa tidak disebut secara langsung dalam Alquran, namun dalam beberapa hadis bukhari membicarakannya. Berbeda dengan Alkitab yang dengan jelas menyebut istri Adam bernama Eve atau Hawa. Kisah Hawa tentunya tidak bisa lepas dari Adam As. Periwayatan dan penciptaan mereka muncul dalam Alquran dan Alkitab. Pemahaman tentang kisahnya pun beragam, sehingga menimbulkan kontroversi dalam memaknai kisah Hawa tersebut.

Islam dan Kristen memiliki ahli tafsir yang menjelaskan maksud atau pesan yang terdapat dalam kitab suci masing-masing dengan latar belakang yang berbeda. Oleh karena itu, penulis mengangkat dua tokoh penafsir dari kedua agama tersebutyakni Muhammad asaddanChristoph Barth

Melihat para peneliti sebelumnya, penulis belum menemukan yang secara khusus membahas kisah Siti Hawa dalam perspektif dua tokoh agama yang berbeda. Namun, terdapat keterkaitan dengan pembahasan Muhammad Asad, penciptaan manusia dan perempuan.Dalam hal ini, urgensi kajian antar agama (interfaith) amat penting untuk memahami secara luas wawasan keagamaan, tidak dibatasi dengan wawasan tentang Islam saja. ${ }^{1}$ Begitu pula dengan kajian tafsirnya, sebab dengan demikian dapat menjawab persoalan yang selama ini menjadi kebingungan dan kontroversi di kalangan masyarakat.

Asad sebagai tokoh cendekiawan muslim yang masyhur dengan latar belakang kelahiran Yahudi telah melakukan perjalanan spiritual yang menghasilkan karya monumental dan diakui oleh berbagai negara di dunia termasuk Indonesia yaitu The Message of the Qur'an. Begitu pula dengan Barth seorang teolog Kristen telah menghasilkan karya besarnya yang berjudul Teologi Perjanjian Lama yang telah digunakan selama 30 tahun di sekolah tinggi teologi dan seminari agung sebagai pegangan.

${ }^{1}$ Sokhi Huda, Studi Agama-Agama (Wacana Pengantar Metodologis, n.d.), 3.
Dalam penelitian ini akan dibahas mengenai ayat-ayat yang berkaitan dengan Siti Hawa dalam Alquran dan Alkitab, penafsiran Muhammad Asad dan Christoph Barth, serta ibrah kisah Siti Hawa dalam pandangan dua tokoh tersebut. Penelitian ini menggunakan metode komparatif juga dengan pendekatan analisis deskriptif.

Dengan mengetahui pemikiran dan penafsiran kedua tokoh tentang kisah Hawa dalam kitab suci masing-masing, diharapkan mampu mengetahui dan memberi solusi bagi pemaknaan kisah Hawa secara benar yang selama ini menjadi kontroversi di kalangan masyarakat.

\section{B. HASIL DAN PEMBAHASAN \\ 1. Kajian Teoritis tentang Hawa dalam Berbagai Literatur Agama-Agama}

\section{a. Yahudi}

Yahudi sebagai agama yang dianut oleh Bani Israel mengakui sosok Adam dan Hawa sebagai manusia pertama di dunia. Dalam agama Yahudi, penjelasan tentang penciptaan manusia dijelaskan dalam Kitab Kejadian dalam ayat-ayat yang membahas tentang penciptaan secara keseluruhan yang terdapat dalam dua teks versi Sakerdotal dan versi Yahwis. Dalam versi Sakerdotal tidak dijelaskan asal-usul penciptaan perempuan, namun dalam versi Yahwis dijelaskan bahwa perempuan diciptakan dari satu bagian dalam tubuh laki-laki. ${ }^{2}$

Dalam tradisi agama ini, perempuan (Hawa) disebut sebagai penyebab jatuhnya Adam dari surga. ${ }^{3}$ Dan karena sejarahnya ini, berdampak pada nasib perempuan pada peradaban di muka bumi, dimana perempuan dikatakan sering memicu terjadinya perang antar kabilah, dan mereka dianggap dan diperlakukan sebagai harta, sampai terjadi peristiwa penguburan anak perempuan.

\section{b. Kristen}

\footnotetext{
${ }^{2}$ Agus Darmaji, "Manusia Dalam Pandangan Yahudi," Jurnal Religi XI, no. 1 (January 2015): 20.

${ }^{3}$ Laila Badriyah, "Epistemologi Pendidikan Islam Menuju Perspektif Gender," Jurnal Al-Hikmah 5 (March 2017): 10.
} 
Sebagaimana halnya Yahudi, Kristen berpandangan bahwa diciptakan dari tulang rusuk Adam dan dikatakan sebagai makhluk ciptaan kedua sebagaimana terdapat dalam Kejadian: 21-23. Selain itu, Hawa juga mempunyai citra sebagai makhluk penggoda dan dekat dengan iblis, karena dalam sejarahnya Hawa telah merayu Adam untuk memakan buah terlarang. ${ }^{4}$ Dalam Alkitab, Adam mematuhi perintah-perintah dan hidup bahagia di surga. Semua persoalannya mulai timbul ketika ada perempuan. ${ }^{5}$ Hawa terhasut oleh bujukan ular untuk memakan buah dari pohon pengetahuan, yang kemudian ia memberikannya kepada Adam. Dan tidak ada seorangpun di antara mereka yang bertanggungjawab, Hawa berkata ular yang membuat ia melakukannya dan Adam berkata bahwa perempuan yang ditempatkan Allah bersamanyalah yang membuat ia memakan buah dari pohon itu. ${ }^{6}$

Berkaitan dengan hal tersebut, agama Kristen memiliki konsep tersendiri tentang dosa. Kisah Adam dan Hawa yang melanggar perintah Tuhan, menjadi sebab putusnya rahmat Tuhan kepada manusia. Adam dan Hawa telah menjerumuskan dirinya dan keturunannya ke dalam "dosa warisan". Kehadiran Yesus Kristus yang diyakini umat Kristen sebagai oknum Tuhan telah menebus dosa manusia dengan kematiannya di tiang salib. ${ }^{7}$

Dalam agama Kristen dosa merupakan sebuah "warisan" yang secara genetik diwarisi manusia dari nenek moyangnya, yang berimplikasi pada terusirnya Adam dan Hawa dari taman Eden karena kemarahan dan kutukan Tuhan. Dengan demikian, dosa

\footnotetext{
${ }^{4}$ Abd. Gafur, "Pendekatan Feminis Dalam Kajian Islam" 2 (oktober 2015): 153-54.

${ }^{5}$ Muhammad Abdul Halim, Memahami AlQur'an Dengan Metode Menafsirkan Al-Qur'an Dengan Al-Qur'an, 1 (Ujungberung: Nuansa, 2008), 175.

${ }^{6}$ Alkitab, Terj. Baru, New International Version (Jakarta: Lembaga Alkitab Indonesia, 2016).

${ }^{7}$ Tarpin, "Pandangan Kristen Tentang Dosa: Asal Muasal Dan Cara Menebusnya" XVI (July 2010): 221.
}

merupakan sesuatu yang melekat dengan manusia, sehingga siapapun memiliki kecenderungan untuk berbuat dosa. ${ }^{8}$

\section{c. Islam}

Dalam Islam kisah Adam dan Hawa diceritakan dalam beberapa surah, dan pemahaman tentang ayat yang berkaitan tidak lepas dari pemikiran para ulama tafsir, baik klasik maupun kontemporer. Di antara pemikiran mufassir tentang kisah Hawa ini, dapat diketahui dalam beberapa tema berikut:

\section{1) PenciptaanSitiHawa}

Tentang penciptaan Siti Hawa yang menjadi perdebatan ulama klasik dan modern dapat ditemui dalam QS. al-Nis̄a [4]: 1 . Mayoritas ulama klasik seperti Ibn Katsīr, alThabary, al-Qurtuby, dan yang lainnyaberpendapat bahwa Hawa diciptakan dari bagian tubuh adam yakni tulang rusuk Adam. Ibn Katsīr dalam tafsirnya menyatakan bahwa Hawa diciptakan dari tulang rusuk Adam bagian kiri dari belakang. ${ }^{9}$ AlTabārimenafsirkan min nafsin wähidah dalam surah al-Nisā ayat 1 tersebut sebagai bagian tubuh Adam, dan kata zawjahā ditafsirkan sebagai Hawa yang diciptakan dari tulang rusuk Adam. ${ }^{10}$ Al-Qurtuby menafsirkan bahwa wanita bersifat bengkok. ${ }^{11}$ Pendapat ketiga tokoh ulama tersebut diperkuat dengan hadits Nabi tentang penciptaan perempuan.

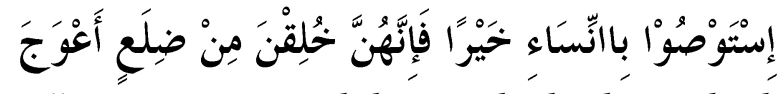

"Pesan-memesanlah untuk berbuat baik kepada perempuan, karena mereka diciptakan dari tulang rusuk yang bengkok ...." (HR. Al-Tirmidzi dari Abu Hurairah).

Muhammad bin Shalih al-Utsaimin dalam karyanya SharhṢahīh Bukhäri menjelaskan bahwa hadis di atas menunjukkan penegasan perintah terhadap seseorang dalam menyikapi

\footnotetext{
${ }^{8}$ Tarpin,"Pandangan Kristen", 221.

${ }^{9}$ Ibnu katsir, Al-Quranul Al-Adzhim, trans. M. Abdul Ghoffar, vol. 2 (Bogor: Pustaka Imam asySyafi'i, 2003), 227.

${ }^{10}$ Al-Thabary, Jami' Al-Bayan Fi Ta'wil AlQur'an, 3rd ed., III (Beirut: Daar al-Kutub al-Ilmiah, 1999), 566.

${ }^{11}$ Al-Qurthuby, Al-Jami' Li Ahkam Al-Qur'an, vol. I (Beirut: Daar al-Kutub al-Ilmiyah, n.d.), 31.
} 
perempuan, bahwa perempuan memiliki sikap lemah dalam hal pikiran, lemah dalam menghadapi persoalan, dan tidak bisa sabar, sehingga seyogyanya seseorang tersebut bersikap lembut terhadap kaum perempuan. ${ }^{12}$

Pandangan mufassir klasik di atas berbeda dengan pendapat mufasssir kontemporer, seperti Muhammad 'Abduh, Rasyid Ridha, Quraish Shihab, Sayyid Qutb, Allamah Kamal Faqih, dan yang lainnya. Menurut Quraish Shihab ulama terdahulu memaknai hadits tentang penciptaan secara harfiah, tidak memahaminya secara metafora, bahkan ada yang menolak kesahihannya. ${ }^{13}$ Lanjut beliau pemahaman nafs yang diartikan sebagai Adam menimbulkan pandangan negatif tentang perempuan, bahwa perempuan adalah bagian dari laki-laki dan tanpa laki-laki perempuan tidak akan ada. ${ }^{14}$ Allamah Kamal Faqih menegaskan bahwa maksud min nafsin wahidah ialah Dia menciptakan istri Adam dari asalnya, bukan dari salah satu bagian tubuh Adam. Menurutnya hadis yang dijadikan dalil oleh ulama klasik sepenuhnya tertolak dan telah ditetapkan bahwa Hawa diciptakan dari tanah sisa penciptaan Adam. ${ }^{15}$ Menurut Sayyid Qutb bahwa hadits yang menyebut Hawa dari tulang rusuk adalah terkontaminasi oleh cerita Israiliyat dimana umat muslim tidak dapat berpegang padanya. Yang pasti menurutnya bahwa Hawa diciptakan dari jenis yang sama dengan Adam. ${ }^{16}$

\section{2) Sebab Jatuhnya Adam}

\footnotetext{
${ }^{12}$ Muhammad bin Shalih Al-Utsaimin, Syarh Shahih Al-Bukhari, Syarah Shahih Al-Bukhari', trans. Fathoni Muhammad dan Muhatadi, 1st ed., vol. 6 (Jakarta Timur: Darus Sunnah Pers, 2012), 579.

${ }^{13}$ M. Quraish Shihab, Tafsir Al-Mishbah, vol. 2 (Jakarta: Lentera Hati, 2012), 399.

${ }^{14}$ M. Quraish Shihab, Wawasan Al-Qur'an: Tafsir Tematik Atas Berbagai Persoalan Umat (Bandung: Mizan Pustaka, 2013), 396.

${ }^{15}$ Allamah Kamal Faqih and Tim Ulama, Nur Al-Qur'an, "An Enlightening Commentary into the Light of the Holy Qur'an”, trans. Anna Farida, vol. 3 (Jakarta: al-Huda, 2006), 474.

${ }^{16}$ Sayyid Quthb, Tafsir Fi Zhilalil-Qur'an, trans. As'ad Yasin dkk (Jakarta: Gema Insani Press, 2003), 158.
}

Dalam menjelaskan kisah Adam dan Hawa, al-Tabārísebagaimana dikutip Prof. Dr. Rosihon Anwar mengatakan bahwa alTabärimengutip riwayat Israiliyat dari Wahhab bin Munabbih bahwa ketika menggoda iblis menggoda Adam dan Hawa, iblis masuk ke surga melalui tubuh ular yang bentuknya berbeda dengan bentuk ular pada umumnya sekarang. ${ }^{17}$ Adapun menurut Ibn Katsīr, iblis menggoda keduanya dari luar pintu surga. ${ }^{18}$

Adapun pendapat mufassir kontemporer seperti Quraish Shihab menyatakan bahwa Allah melarang Adam dan Hawa mendekati satu pohon yang ada di surga, karena jika mereka mendekatinya apalagi memakan buahnya mereka termasuk orang yang zhalim dalam arti tidak menempatkan sesuatu pada tempatnya. Dan hal ini menandakan kasih sayang Allah kepada Adam dan Hawa serta keturunannya bahwa Allah mengetahui ada kecenderungan manusia untuk berhasrat, sehingga Allah batasi dengan larangan tersebut. ${ }^{19}$ Selanjutnya Allamah Kamal Faqih menyebutkan bahwa iblis menggoda Adam dan Hawa dalam bentuk seorang teman dan seorang yang dermawan. ${ }^{20}$ Menurut Sayyid Quthb setan membisikkan kejahatan kepada keduanya untuk menampakkan aurat mereka. $^{21}$

\section{3) Hukuman}

Allah menegeluarkan keduanya dari surga, menurut Ibn Katsīr ialah sebagai balasan terhadap keinginan mereka. Namun, Allah mengampuni dosa dan telah menerima taubat mereka. Quraish Shihab menyatakan

\footnotetext{
${ }^{17}$ Rosihon Anwar, Melacak Unsur-Unsur Israiliyyat Dalam Tafsir Ath-Thabari Dan Tafsir Ibnu Katsir (Bandung: Pustaka Setia, 1999), 100.

${ }^{18}$ Ibnu Katsir, Lubaabut Tafsiir Min Ibnu Katsiir, trans. M. Abdul Ghoffar E.M dan Abdurrahim Mu'thi, vol. 1 (Bogor: Pustaka Imam asy-Syafi'i, 2003), 112.

${ }^{19}$ M. Quraish Shihab, Tafsir Al-Mishbah (Jakarta: Lentera Hati, 2012), 43.

${ }^{20}$ Allamah Kamal Faqih dan tim ulama, Nur Al-Qur'an, 406-7.

${ }^{21}$ Sayyid Quthb, Tafsir Fi Zhilalil-Qur'an, n.d., 160 .
} 
hendaknya pengusiran mereka dari surga mendorong mereka untuk kembali ke surga dengan cara yang Allah tunjukkan. ${ }^{22}$ Menurut Kamal Faqih pengusiran mereka bukan sebagai hukuman, karena yang terjadi kepada mereka hanya karena mereka meninggalkan yang lebih baik, jika tidak maka akan lebih baik. $^{23}$ Sayyid Quthb megaskan bahwa maksud QS. al-A'rāf [7]: 23 ialah menunjukkan keistemewaan mansia yang menghubungkannya dengan Tuhan dan membukakan pintu taubat disertai dengan keyakinan bahwa mereka tidak berdaya dan tidak memiliki kekuatan tanpa pertolongan Allah. $^{24}$

\section{4) PenafsiranFeminis Muslim}

Amina Wadud seorang feminis muslimah berkenaan dengan penafsiran QS. al-Nis $\bar{a}$ ayat 1 berkomentar bahwa penafsiran mufassir klasik terhadap ayat ini perlu dikritik ulang terlebih penafsiran pada kata nafs wahidah, min dan zawj. Menurut Amina "sebenarnya ayat tersebut hanya menunjukkan unsur pokok kisah asal usul manusia versi Alquran, tanpa memberi kejelasan tentang Adam dan Hawa. Dan menurutnya kata "min" ialah "yang sejenisnya" atau "sama jenisnya", sehingga Hawa berarti diciptakan dari jenis yang sama dengan Adam. ${ }^{25}$ Menurut Riffat Hassan konsep penciptaan yang menjadi perdebatan pada surah an-Nisa ayat 1 menyatakan bahwa kata Adam adalah istilah Ibrani dan kata Adamah berarti tanah yang berfungsi sebagai istilah genetik untuk manusia. $^{26}$

Alquran menempatkan laki-laki dan perempuan sebagai dua jenis makhluk yang

\footnotetext{
${ }^{22}$ M. Quraish Shihab, Tafsir Al-Mishbah, vol. 1 (Jakarta: Lentera Hati, 2012), 194.

${ }^{23}$ Allamah Kamal Faqih dan tim ulama, Nur Al-Qur'an, n.d., 410. 162.

${ }^{24}$ Sayyid Quthb, Tafsir Fi Zhilalil-Qur'an, n.d.,

${ }^{25}$ Ernita Dewi, "Pemikiran Amina Wadud Tentang Rekonstruksi Penafsiran Berbasis Metode Hermeneutika," Jurnal Substantia 15 (Oktober 2013): 51-52.

${ }^{26}$ Mutrofin, "Kesetaraan Gender Dalam Pandangan Amina Wadud Dan Riffat Hassan," Jurnal Tasawuf Dan Pemikiran Islam 3 (June 2013): 255.
}

memiliki status yang sama yakni sebagai 'abid dan khalifah. Antara keduanya tidak tidak terdapat superioritas, baik dari segi asal-usul maupun dari segi statusnya. Dengan demikian konsep feminisme dalam Alquran tidak mesti mengandung konotasi bahwa perempuan berada di bawah otoritas dan superioritas kaum laki-laki. ${ }^{27}$

\section{Muhammad Asad dan Christoph Barth serta Penafsirannya tentang Siti Hawa
a. Biografi Muhammad Asad dan karyanya

Muhammad Asad nama aslinya adalah Leopold Weiss, ia lahir di Lemberg, AustriaHongaria pada tahun 1900 sebagai keluarga keturunan Yahudi. ${ }^{28}$ Keluarganya secara turun temurun adalah rabbi, kecuali ayahnya yang menjadi seorang pengacara. Sejak kecil ia belajar agama, hingga berkenalan dengan bahasa Ram, Perjanjian Lama, serta teks-teks maupun tafsir dari Talmud, Mishna, Gemara dan Targum. ${ }^{29}$ Ibunya adalah seorang dari empat putri bankir kaya di kota Livow dibagian sebelah Timur Gacilia. ${ }^{30}$

Ayahnya berharap ia menjadi seorang ahli ilmu pengetahuan, namun dalam perjalanannya Weiss lebih memilih menjadi seorang wartawan. ${ }^{31}$ Pada tahun 1922 ia menginap di rumah pamannya di Palestina, dari sini mata dan hatinya tersentak melihat realita kehidupan yang berbeda dengan Eropa. Menurutnya, pengetahuan orang Eropa tentang orang Arab praktis tidak tepat. Pada tahun ini pula ia bekerja menjadi koresponden Harian Surat Kabar Jerman terkemuka, Frankfurt Zeitung, untuk wilayah Timur Dekat. Ia berkunjung ke berbagai negara di Timur Tengah dan menghabiskan sebagian

\footnotetext{
${ }^{27}$ Abudin Nata et al, Kajian Tematik Al-Qur'an Tentang Kemasyarakatan (Bandung: Angkasa Bandung, 2008), 232.

${ }^{28}$ Mohammad Asad, Islam Di Simpang Jalan, 1st ed. (Bandung: Sega Arsy, 2015), 7.

${ }^{29}$ Mohammad Asad, The Road to Mecca: Perjalanan Spiritual Seorang Pencari Kebenaran, trans. Fuad Hashem, I (Bandung: Mizan, 2003), 87.

${ }^{30}$ Mohammad Asad, 87.

${ }^{31}$ Mohammad Asad, 100
} 
besar waktunya di sana. Dari sanalah ia mulai berkenalan dengan Islam, peradaban, kebudayaan, serta perilaku umatnya. ${ }^{32}$

Weiss masuk Islam pada tahun 1926 di Berlin saat ia kembali ke Eropa dan mengubah namanya menjadi Muhammad Asad. Setelah menjadi seorang muslim, ia mempelajari Alquran, Hadits, sejarah serta buku-buku tentang Islam. ${ }^{33}$ Setelah masuk Islam ia tinggal selama hampir enam tahun di Arabia dan bersahabat dengan Ibn Saud, kemudian pergi ke India dan bertemu dengan Muhammad Iqbal. Beliaulah yang mengusulkan Asad tinggal di India untuk membantunya memperteguh dasar-dasar pemikiran bagi masa depan Islam.

Pada tahun 1947 Asad diangkat menjadi kepala Departmen Rekonstruksi Islam, kemudian setelah dua tahun di dipindahkan tugas sebagai Kepala Bagian Timur Tengah pada Kementrian Luar Negeri untuk memperkukuh antara Pakistan dengan dunia Islam lainnya, selanjutnya ia ditunjuk sebagai utusan Pakistan untuk PBB. Pada tahun 1952, Asad melatakkan jabatannya dan mulai menulis buku The Road to Mecca. Bertahuntahun Asad mengabdikan dirinya untuk Islam, dengan belajar, menulis, memberikan kuliahkuliah hingga ia menyandang reputasi sebagai seorang penafsir hukum dan kebudayaan Islam dengan karyanya Manhaj al-Islam fi al-Hukm. Karya paling fenomenal dan monumental yang dihasilkannya ialah The Message of the Qur'an sebuah kitab tafsir dan terjemah Alquran ke dalam bahasa Inggris. Ketika mulai menulis karya ini pada tahun 1920-an ia harus tinggal bertahun-tahun dengan suku Badui Arab untuk memperolah wawasan semantik bahasa Alquran, karena pada masa itu orang-orang Badui masih banyak yang menggunakan bahasa yang dipergunakan Alquran. dan pada tahun 1992 Asad meninggal, jenazahnya dimakamkan di pemakaman Muslim Granada, Andalusia.

8.

${ }^{32}$ Mohammad Asad, Islam Di Simpang Jalan,

${ }^{33}$ Mohammad Asad, 9.

\section{b. Biografi Christoph Barth dan karyanya}

Christoph Barth adalah anak Karl Barth, ia lahir pada tahun 1917 di negeri Swiss, telah menyelesaikan pendidikannya di Basel dan Leiden untuk gelar teologinya pada tahun 1947. Ia adalah seorang pendeta jemaat dan juga seorang doktor teologi. Pernah menjadi dosen di beberapa sekolah teologi di Indonesia, di antaranya Sekolah Teologi di Banjarmasin (1947-1952), HTS Jakarta (1953), STT Jakarta (1954) dan Institut Teologi di Ambon (1964). Selain pernah menjadi dosen di beberapa sekolah Teologi di Indonesia, Barth juga pernah menjadi guru besar di Jerman Universitas Mainz (19671979). Oleh murid-muridnya di Indonesia, ia dikenal dengan nama julukan "Sihabar" (untuk Chr. Barth!). ${ }^{34}$

Ia sangat mencintai Perjanjian Lama sejak masa studinya, ia memahaminya sebagai suatu kor memuji Allah dengan suara sebagai saksi dan sebagai petunjuk untuk hidup menurut kehendak Allah. Karya utamanya adalah Teologi Perjanjian Lama yang merupakan bentuk terakhir dari kuliah yang ia berikan selaku dosen dibeberapa sekolah tinggi di Indonesia. Dalam karyanya ini Barth mengembangkan metode dari Gerhard Von Rad, dan bukunya telah disajikan kepada calon pendeta di Gereja Kalimantan Evangelis.

Tahun 1965 ia kembali ke Swiss ia memilih fokus menyelesaikan karyanya ini di tanah air dan mengurungkan cita-citanya untuk kembali mengabdi di Gereja dan Universitas di Indonesia. Karena menurutnya jika bukunya selesai, maka akan lebih bermanfaat dibandingkan pengajaran lisan yang terbatas pada satu tempat, namun tidak mendalaminya. Maka selesailah buku Teologi $P L$ bagian pertama ini dalam dua tahun. ${ }^{35}$ Buku Teologi Perjanjian Lama ini ditulis dalam bahasa Indonesia, yang terbagi kedalam empat jilid dan telah melalui proses panjang. Edisi

\footnotetext{
${ }^{34}$ Barth, Teologi Perjanjian Lama, 1st ed., vol. 1, n.d.

${ }^{35}$ Barth, Teologi Perjanjian Lama, 1st ed., vol. 1, n.d.
} 
pertama buku Teologi PL ini diterbitkan oleh BPK. Gunung Mulia pada 1970; dua belas tahun kemudian baru muncul jilid ke 2 (1982); pada tahun 1985 terbit jilid 3; dan jilid ke empat masih berbentuk 'draft', yang pada akhirnya diselesaikan oleh istrinya atas permintaan Barth ketika ia sakit berdasarkan catatannya kepada sang istri Marie-Claire Barth-Frommel, pada tahun 1988 setelah suaminya meninggal pada tahun 1986. Marie juga merevisi Teologi PL 1 atas tugas dari BPK Gunung Mulia, ia merivisi banyak perubahan kecuali di Bab I tentang penciptaan ia tulis ulang. Perubahannya didasarkan pada temuan ilmiah dan persoalan-persoalan etika sosial selama tiga puluh tahun terkahir penelitiannya. Buku karya Barth ini sudah digunakan selama 30 tahun di sekolah tinggi teologi dan seminari agung sebagai buku pegangan. $^{36}$

\section{c. Penafsiran Muḥammad Asad dan Christoph Barth tentang Siti Hawa}

\section{1.) PenciptaanSitiHawa}

Dalam Alquran, kisah Siti Hawa tidak lepas dari kisah Nabi Adam a.s. sehingga secara keseluruhan ditemukan 65 ayat kisah Adam dan Hawa yang tersebar dalam lima surah yakni QS. al-Baqarah [2]: 30-39, QS. al-A'rāf [7]: 11-27, QS. al-Hijr (15): 26-43, QS. Thāhā (20): 115-124, dan QS. Șhad [38]: 71-85. ${ }^{37}$ Namun, penulis menemukan 21 ayat yang secara spesifik mengisahkan tentang Siti Hawa yang tersebar dalam enam surah. Dalam Bible, kisah tentang Hawa terdapat dalam Perjanjian Lama, Kitab Kejadian: 2 dan 3.

Berkenaan dengan penciptaan perempuan pertama di dunia, ditemukan empat ayat yang tersebar dalam empat surah yang mengisahkan tentang penciptaan Siti Hawa dalam Alquran. Yakni QS. al-Nisā [4]: 1, QS. al-Naḥl [16]: 72, QS. al-A'rāf [7]: 189, dan QS. al-Zumar

\footnotetext{
${ }^{36}$ Claire, Teologi Perjanjian Lama, 1st ed., vol. 1, n.d.

${ }^{37}$ Barbara Freyer Stowasser, Reinterpretasi Gender: Wanita Dalam Alquran, Hadis, Dan Tafsir, trans. H.M. Mochtar Zoerni (bandung: Pustaka Hidayah, 2001), 67.
}

[39]: 6. Sedangkan dalam Bible, terdapat dalam kitab Kejadian ayat 2: 21-24.

Menurut penafsiran Asad dan Barth tentang asal-usul penciptaan Hawa ini, keduanya sama-sama memperhatikan kesetaraan antara laki-laki dan perempuan. Namun, pendapat mereka tentang material penciptaan Hawa berbeda. Jika menurut Asad, Hawa tercipta dari "entitas hidup yang satu" dalam arti jenis yang sama dengan Adam, dengan alasan yang sama yakni asal-usul yang sama dan persaudaraan umat manusia. ${ }^{38}$ Namun menurut Barth, Hawa tercipta dari panggul laki-laki, tetapi karena semua lakilaki lahir dari tubuh ibunya, dan Adam mengakui Hawa sebagai keluarganya, maka keseimbangan laki-laki dan perempuan tetap terjaga, tidak seperti penafsiran orang-orang terdahulu yang selalu menganggap bahwa perempuan diperbantukan karena ia nomor dua. $^{39}$

\section{2.)SebabJatuhnya Adam}

Dalam Alquran, ayat-ayat yang membahas tentang sebab jatuhnya Adam terdapat dalam 12 ayat yang tersebar dalam tiga surah yang berbeda, di antaranya QS. al-Baqarah [2]: 3536; QS. al-A'rāf [7]: 19-22 dan QS. Thāhā [20]: 115-118. Sedangkan dalam Bible terdapat dalam Kejadian: 3: 1-13.

Berkenaan dengan ayat-ayat yang berkaitan dengan sebab jatuhnya Adam ini kedua tokoh Muhammad Asad dan Christoph Barth sependapat bahwa dibalik kisah ini mengisyaratkan pada kenyataannya manusia memiliki keterbatasan dan ketidakberdayaan total yang disebut Asad sebagai kelemahan moral (kelalaian manusia akan perintah Allah, karena hilangnya keteguhan cita-cita dalam ranah akhlak), ${ }^{40}$ sehingga mereka memerlukan batasan dan patokan hidup, agar tidak hidup

\footnotetext{
${ }^{38}$ MuhammadAsad, The Message of the Qur'an: Tafsir Bagi Orang-Orang Yang Berpikir, , trans. Tim Penerjemah Mizan, 1 (Bandung: Mizan Pustaka, 2017), 124.

${ }^{39}$ Christoph Barthdan Marie-Claire BarthFrommel, Teologi Perjanjian Lama 1, 8th ed. (Jakarta: BPK Gunung Mulia, 2017), 38.

${ }^{40}$ MuhammadAsad, The Message of the Qur'an: Tafsir Bagi Orang-Orang Yang Berpikir, 600.
} 
sebebas-bebasnya yang dengannya Asad menyebut pohon itu sebagai batasan terhadap hasrat manusia. ${ }^{41}$ Menurut Asad, kesengsaraan akan didapatkan manusia karena ia mengikuti godaan setan untuk memilih jalan yang salah dan melanggar perintah Tuhan ${ }^{42}$.Oleh karena itu, lanjut Asad kemampuan konseptual merupakan anugerah luar biasa yang diberikan kepada manusia. Dan menurut kedua tokoh tersebut, kisah ini menyadarkan manusia, bahwa mereka bergantung dan memerlukan tuntunan Tuhan. ${ }^{43}$

Disisi lain keduanya bertentangan. Menurut Asad, jelas dalam Alquran bahwa setan membujuk keduanya (Adam dan Hawa) memakan buah dari pohon itu. ${ }^{44}$ Adapun Barth memandang bahwa ular hanya membujuk Hawa saja, ${ }^{45}$ sehingga pada saat Allah memanggil Adam dan Hawa untuk meminta pertanggungjawaban, mereka enggan mengakui kesalahan dan malah saling menjatuhkan. Inilah yang menurut Barth mengisyaratkan bahwa manusia jarang rela mengaku dirinya salah. ${ }^{46}$ Selain itu, Barth berasumsi adanya dosa aktif dan pasif. ${ }^{47}$ Dalam hal ini, kedua tokoh sangat rinci menjelaskan kisah kejatuhan ini, dimana keduanya sama-sama memperlihatkan gambaran Adam dan Hawa dengan umat sekarang. Bedanya, Asad lebih memandang pada nilai moral sebagai 'ibrah dari kisah ini. Adapun Barth lebih ke bukti konkret yang terjadi saat ini.

\section{3.) Hukuman}

Ayat-ayat yang berkaitan dengan hukuman, ditemukan lima ayat yang tersebar dalam tiga surah yang berbeda yakni QS. al-Baqarah [2]: 37, QS. al-A'rāf [7]: 23-24 dan QS. Thāhā [20]: 122-123. Adapun dalam Bible, ayat tentang hukuman Adam dan Hawa terdapat dalam Kejadian: 3: 14-18 dan 23.

\footnotetext{
${ }^{41}$ Asad, The Message of the Qur'an, n.d., 600.

${ }^{42}$ Asad, The Message of the Qur'an, n.d., 251.

${ }^{43}$ Asad, The Message of the Qur'an, n.d., 600.

${ }^{44}$ Asad, The Message of the Qur'an, n.d., 14.

${ }^{45}$ Barth, Teologi Perjanjian Lama, n.d., 1:39.

${ }^{46}$ Barth, Teologi Perjanjian Lama, n.d., 1:41.

${ }^{47}$ Barth, Teologi Perjanjian Lama, n.d., 1:40.
}

Konteks ayat Alquran dan Alkitab ini menceritakan akibat yang telah dilakukan Adam dan Hawa karena melanggar perintah Tuhan. Dalam tafsir The Message of the Qur'an dan Teologi Perjanjian Lama samasama mengungkapkan akibat dan nilai dibalik kisah jatuhnya Adam, namun keduanya berbeda pendapat. Asad memandang pembakangan terhadap perintah Tuhan yang dilakukan Adam dan Hawa adalan takdir dan merupakan simbol pertumbuhan kesadaran. Hal ini merupakan tingkatan baru dan perkembangan manusia dengan terbukanya gerbang menuju pertimbangan moral yang menjadikannya berbeda dengan makhluk lain ${ }^{48}$.Dan dalam Alquran jelas bahwa Adam dan Hawa diampuni sesuai tuntunan firmanNya.

Berbeda halnya dengan Barth, ia memahami kisah kejatuhan ini sebagai akibat, dan menurutnya akibat harus dibayar dengan hukuman, seperti inti kehidupan laki-laki dan perempuan menjadi sulit. Namun, Barth tidak sependapat dengan paham yang mengatakan bahwa laki-laki berkuasa atas perempuan sebagaimana dipahami oleh kaum patriarkhal.

Barth juga menolak paham yang mengakar di umat Kristen berkenaan dengan adanya "dosa warisan" dari Hawa, menurutnya hal ini tidak dapat dibenarkan berdasarkan Perjanjian Lama. ${ }^{49}$

Berdasarkan uraian di atas, penulis menemukan maksud Asad "nilai moral dari kisah ini berlaku untuk umat secara keseluruhan" (QS. al-Baqarah [2]: 36) adalah bahwa kisah Adam dan Hawa ini hikmah dan pelajarannya dapat ditafakuri dan menjadi contoh untuk umat dulu, sekarang dan seterusnya. Dan dibalik kisahnya, Allah mempunyai maksud tersendiri yang menunjukkan ke-Maha Esaan Dia atas segala sesuatu. Adapun Barth memahami akibat dari apa yang dilakukan Adam dan Hawa itu digambarkan berupa berbagai kesulitan yang akan dialami umat manusia, baik laki-laki

\footnotetext{
${ }^{48}$ Asad, The Message of the Qur'an, n.d., 252.

${ }^{49}$ Barth, Teologi Perjanjian Lama, n.d., 1:42.

${ }^{50}$ Asad, The Message of the Qur'an, n.d., 14.
} 
maupun perempuan. Penulis memahaminya, hal demikian sama sekali dipandang Barth bukan sebagai dosa warisan melainkan ketentuan atau ketetapan Allah yang semestinya dijalani manusia dalam hidupnya.

\section{SIMPULAN}

Muhammad Asad sebagai tokoh cendekiawan muslim yang terlahir dari keturunan Yahudi, pemikirannya sama sekali tidak terkontaminasi oleh pemikiran orangorang Yahudi yang nilai keagamaannya melekat dalam keluarganya. Justru, semakin ia mengenal Yahudi setelah masuk Islam ia semakin yakin bahwa Islam-lah agama yang selama ini ia cari. Begitu pula dengan Christoph Barth, pemahaman Kristen tentang "dosa warisan" yang telah melekat pada umatnya tidak mempengaruhi pemikirannya, karena menurutnya hal demikian tidak sesuai dengan Perjanjian Lama.

Berdasarkan analisa penulis, kedua tokoh ini sama-sama menjunjung tinggi kesetaraan laki-laki dan perempuan sesuai dengan pemahaman agama masing-masing. Mereka memandang kisah kejatuhan Adam danHawaini menyadarkan manusia akan keterbatasan dan ketidakberdayaannya yang membutuhkan petunjuk dan pertolongan Tuhan. Menurut Asad, jika manusia melanggar perintah Tuhan, maka ia akan mendapat kesengsaraan. Adapun penulis berpendapat bahwa dengan ini menunjukkan bahwa rahmat Allah akan terputus jika manusia melanggar perintah-Nya. Asad tidak memandang kejatuhan ini sebagai hukuman, menurutnya nilai moral dari kisah ini bukan tentang kisah masa lampau, tetapi lebih kepada pertumbuhan kesadaran, perkembangan manusia menuju pertimbangan moral. Adapun Barth memandang bahwa akibat harus dibalas dengan hukuman yang akan dirasakan Adam dan Hawa di bumi. Namun, pada prisnsipnya keduanya berpandangan bahwa Tuhan tidak pernah membedakan manusia berdasarkan jenis kelamin.

\section{DAFTAR PUSTAKA}

Abd. Gafur. "Pendekatan Feminis Dalam Kajian Islam" 2 (oktober 2015): 153-54.

Abudin Nata et al. Kajian Tematik Al-Qur'an Tentang Kemasyarakatan. Bandung: Angkasa Bandung, 2008.

Agus Darmaji. "Manusia Dalam Pandangan Yahudi." Jurnal Religi XI, no. 1 (January 2015).

Alkitab. Terj. Baru, New International Version. Jakarta: Lembaga Alkitab Indonesia, 2016.

Allamah Kamal Faqih, and Tim Ulama. Nur Al-Qur'an, "An Enlightening Commentary into the Light of the Holy Qur'an". Translated by Anna Farida. Vol. 3\& 6. Jakarta: al-Huda, 2006.

Al-Qurthuby. Al-Jami' Li Ahkam Al-Qur'an. Vol. I. Beirut: Daar al-Kutub al-Ilmiyah, n.d.

Al-Thabary. Jami' Al-Bayan Fi Ta'wil AlQur'an. 3rd ed. III. Beirut: Daar al-Kutub al-Ilmiah, 1999.

Asad. The Message of the Qur'an, n.d.

- The Message of the Qur'an, n.d.

Barbara Freyer Stowasser. Reinterpretasi Gender: Wanita Dalam Alquran, Hadis, Dan Tafsir. Translated by H.M. Mochtar Zoerni. Bandung: Pustaka Hidayah, 2001.

Barth. Teologi Perjanjian Lama. 1st ed. Vol. 1, n.d. 1, n.d.

Christoph Barthdan Marie-Claire BarthFrommel. Teologi Perjanjian Lama 1. 8th ed. Jakarta: BPK Gunung Mulia, 2017.

Claire. Teologi Perjanjian Lama. 1st ed. Vol. 1, n.d.

Ernita Dewi. "Pemikiran Amina Wadud Tentang Rekonstruksi Penafsiran Berbasis Metode Hermeneutika." Jurnal Substantia 15 (Oktober 2013): 51-52.

Ibnu Katsir. Al-Quranul Al- Adzhim. Translated by M. Abdul Ghoffar. Vol. 2. Bogor: Pustaka Imam asy-Syafi'i, 2003. . Lubaabut Tafsiir Min Ibnu Katsiir. Translated by M. Abdul Ghoffar E.M dan Abdurrahim Mu'thi. Vol. 1. Bogor: Pustaka Imam asy-Syafi' 'i, 2003.

Laila Badriyah. "Epistemologi Pendidikan 
Siti Hawa Dalam Perspektif MuḥAmmad Asad Dan Christoph Barth

Islam Menuju Perspektif Gender.” Jurnal Al-Hikmah 5 (March 2017): 10.

M. Quraish Shihab. Tafsir Al-Mishbah. Vol. 2. Jakarta: Lentera Hati, 2012.

- Tafsir Al-Mishbah. Jakarta: Lentera Hati, 2012.

_. Tafsir Al-Mishbah. Vol. 1. Jakarta: Lentera Hati, 2012.

—. Wawasan Al-Qur'an: Tafsir Tematik Atas Berbagai Persoalan Umat. Bandung: Mizan Pustaka, 2013.

Mohammad Asad. Islam Di Simpang Jalan. 1st ed. Bandung: Sega Arsy, 2015.

- The Road to Mecca: Perjalanan Spiritual Seorang Pencari Kebenaran. Translated by Fuad Hashem. I. Bandung: Mizan, 2003.

Muhammad Abdul Halim. Memahami AlQur'an Dengan Metode Menafsirkan AlQur'an Dengan Al-Qur'an. 1. Ujungberung: Nuansa, 2008.

Muhammad bin Shalih Al-Utsaimin, SharhṢahīh Al-Bukhari. Syarah Sahīh AlBukhari'. Translated by Fathoni Muhammad dan Muhatadi. 1st ed. Vol. 6. Jakarta Timur: Darus Sunnah Pers, 2012.
MuhammadAsad. The Message of the Qur'an: Tafsir Bagi Orang-Orang Yang Berpikir, The Message Og The Qur'an. Translated by Tim Penerjemah Mizan. 1. Bandung: Mizan Pustaka, 2017.

Mutrofin. "Kesetaraan Gender Dalam Pandangan Amina Wadud Dan Riffat Hassan." Jurnal Tasawuf Dan Pemikiran Islam 3 (June 2013): 255.

Rosihon Anwar. Melacak Unsur-Unsur Israiliyyat Dalam Tafsir Ath-Thabari Dan Tafsir Ibnu Katsir. Bandung: Pustaka Setia, 1999.

Sayyid Quthb. Tafsir Fi Zhilalil-Qur'an. Translated by As'ad Yasin dkk. Jakarta: Gema Insani Press, 2003.

- Tafsir Fi Zhilalil-Qur'an, n.d.

- Tafsir Fi Zhilalil-Qur'an, n.d.

Sokhi Huda. Studi Agama-Agama. Wacana Pengantar Metodologis, n.d.

Tarpin. "Pandangan Kristen Tentang Dosa: Asal Muasal Dan Cara Menebusnya" XVI (July 2010): 221. 